\title{
Consumer perception of global branded products quality
}

\author{
Pavol Kral ${ }^{1, *}$, Katarina Janoskova ${ }^{2}$ \\ ${ }^{1}$ University of Zilina, Faculty of Operation and Economics of Transport and Communication, \\ Department of Economics, Univerzitna 8215/1, 01016 Zilina, Slovak Republic \\ ${ }^{2}$ University of Zilina, Faculty of Operation and Economics of Transport and Communication, \\ Department of Economics, Univerzitna 8215/1, 01016 Zilina, Slovak Republic
}

\begin{abstract}
The brand plays the key part in consumer decision-making on products, and it is crucially important to both producer and consumer. The long-term globalization process has significantly influenced international brand policy. A successful brand in the domestic market is not a prerequisite of success in global markets. Successful global brand reflect on the rational as well as emotional customer expectations and desires that may change over time. The consumers generally consider branded product to the significant of quality, and they are likely to opt for the proven brand rather than even considering also the other brands available. The aim of this paper is to evaluate the relationship between selected sociodemographic characteristics (gender, age, education) and the subjective perception of selected global brands (branded products) quality by current consumers using selected mathematical-statistical methods. We realized a large-scale marketing survey was conducted on a sample of consumers (total 2002 respondents) with a minimum age of 15 years in 2018. The analysis results show relationship of different nature and intensity between socio-demographic characteristics of respondents and their attitudes towards quality of branded products. Conclusions and findings of analysis can be considered appropriate to apply to current consumer markets. The findings of the survey proved that effective branding strategies shall respect, inter alia, pursue the also socio-demographic trends consumers markets. The socio-demographic characteristics of consumers shall be considered the reliable selection criterion for determining both attractivity and potential of the brand in terms of the success of the brand.
\end{abstract}

\section{Introduction}

Brand is considered the effective marketing tool since the concept first appeared. The brand plays the key part in consumer decision-making on products, and it is crucially important to both producers and consumer. The consumers find the brand to be the significant quality of the product, and they are likely to opt for the proven brand rather than even considering

\footnotetext{
* Corresponding author: pavol.kral@fpedas.uniza.sk
} 
also the other brands available. Thus, the brand shall be considered the attribute of great importance when it comes to the consumer decision-making about the product.

This research is to identify the correlation between selected socio-demographic characteristics (gender, age, education, income) and quality perception of branded products (global brands) by Slovak consumers, using a mathematical and statistical apparatus. The socio-demographic characteristics of consumer markets shall be considered the key determinants that effective branding strategies have to reflect. A comprehensive marketing survey has been carried out involving Slovak consumers. The results of the survey shows a direct correlation, but varying in character and intensity, between selected sociodemographic characteristics of respondents vs quality perception of branded products.

\section{Literature review}

Customer satisfaction is considered as a significant determinant of business success. Entrepreneurs are aware of this and therefore try to find out which factors affect customer satisfaction. Brand name plays crucial roles in consumer perceptions and evaluations [1]. A brand is a very broad concept. It is a combination of everything that a customer takes into account in the purchasing decision-making process. It is not only a trademark but also the associations that arise in the minds of consumers when remembering a specific brand. The brand strikes an emotion in consumers. This is a combination of consumer experience with the brand since the very first „touch“ of the product [2].

The brand strikes an emotion in consumers. This is a combination of consumer experience with the brand since the very first ,touch“ of the product $[3,4,5,6]$. Brands have a different meaning for each consumer, which helps develop the purchasing trends. In relation to the consumer, the brand consists of important elements. Mostly, it is the significance of a brand expressing the way the consumer perceives the brand within its rational and emotional advantages [7]. All brands aiming at building a strong competitive position in the market need to be able to reinforce their image. This is the reason why managers have stressed brands engaging in activities such as advertising and public relations [8].

The brand is in fact a factor that significantly affets the buying decesion of the consumer and their satisfaction [9]. An important criterion that is usually associated with a brand is quality. It is important to say that consumers infer the quality of the product based on the displayed signals such as qualaity labels, certification marks, or seals approval $[10,11]$. Many studies deal with the issue ofcusomer satisfaction in the context of customers' personal charactersitics. Research realized by [12] is based on the assumption that personal characteristics influence satisfaction as well as how the customer views satisfaction. The main personal characteristiscs used in their research were gender, age and income.

Many authors have shown that customer positive feelings, emotions toward a brand have a positive impact on certain brand outcome variables, such as brand loyalty, brand equity, brand trust, positive brand market share etc. [13, 14, 15, 16, 17]. There are two main constructs in which literature consider the main factors to position a brand [12]:

1. the consumer perceptions of the quality of the brand

2. consumer perceptions of the price of the brand in firm's portfolio.

Morgan \& Rego [19] posit that achieve both positions (quality and price) simultaneously for all the brands in a firm's portfolio may also be difficult and relatively rare in practice. For example, consumers often use price as a quality cue, making it difficult to achieve perceptions of both high quality and low price. In addition, achieving strong quality perceptions among consumers is often expensive because it may involve using 
higher-quality raw materials or better-trained service operatives, superior manufacturing or operations technologies, and greater marketing communication expenditures.

\section{Methods}

Anextensive marketing surveywas carried out to determinethepreferences and attitudes of Slovak consumers towards brands, i.e. to indicate key endogenous and exogenous factors determining the consumers'preferencesfor the brand within athoroughsector structure of the national economy and also to identify the triggers determining theconsumers' attitudes towards the brand, using individual marketing mix tools.

The survey sample (hereinafter the target group) involved Slovak consumers, regardless ofgender, social status, monthly income or place of residence. The collection of the data took place in March 2018. The only restriction in terms of the socio-demographics was set on the age of the respondents, i.e. the minimum age of 16.

The survey questionnaire consisted of 34 questions, mostly the closed-ended (selective) questions, which tend to be more preferred by most respondents. The questionnaire was divided into three parts from the point of view of the context, and which are as follows: the first part dealing with consumer preferences and attitudes towards brands in general, the second part addressing specific cost-saving scenariosin4selected areas: automobiles, banks, cola drinks and sportswear; and the last one mapping the socio-demographic characteristics of consumers, i.e. respondents, which are as follows.

- gender

- age

- place of residence

- other persons living in the common household

- education

- social status

- net monthly household income

The Table 1 below provides on the socio-demographic characteristics of the target group.

Table 1. Selected Socio-Demographic Data Frequency Overview.

\begin{tabular}{|c|c|c|c|c|c|c|}
\hline Gender & & male & & \multicolumn{3}{|c|}{ female } \\
\hline Frequency & \multicolumn{3}{|c|}{$\frac{\text { male }}{985(49 \%)}$} & \multicolumn{3}{|c|}{$1017(51 \%)$} \\
\hline Age & 16-25 & $26-35$ & $36-45$ & $46-55$ & $55-65$ & over 66 \\
\hline Frequency & $438(22 \%)$ & $423(21 \%)$ & $377(19 \%)$ & $381(19 \%)$ & $293(15 \%)$ & $90(4 \%)$ \\
\hline Education & \multicolumn{2}{|c|}{ primary/vocational } & \multicolumn{2}{|c|}{ secondary } & \multicolumn{2}{|c|}{ university } \\
\hline Frequency & \multicolumn{2}{|c|}{$1071(53 \%)$} & \multicolumn{2}{|c|}{$687(34 \%)$} & \multicolumn{2}{|c|}{$244(12 \%)$} \\
\hline Social Status & student & employed & unemployed & $\begin{array}{c}\text { self- } \\
\text { employed }\end{array}$ & retired & $\begin{array}{c}\text { maternity } \\
\text { leave }\end{array}$ \\
\hline Frequency & $330(16 \%)$ & $965(48 \%)$ & $128(6 \%)$ & $123(6 \%)$ & $314(16 \%)$ & $142(7 \%)$ \\
\hline $\begin{array}{l}\text { Net Monthly } \\
\text { Household } \\
\text { Income } \\
\text { (EUR) }\end{array}$ & $<500$ & $501-1000$ & $1001-1500$ & $1501-2000$ & 2001-2500 & $>2500$ \\
\hline Frequency & $342(17 \%)$ & $692(35 \%)$ & $558(28 \%)$ & $255(13 \%)$ & $88(4 \%)$ & $67(3 \%)$ \\
\hline
\end{tabular}

The acquired primary data enabled us to carry out the formulated statistical hypothesis test with the goal to identify mutual causations between the selected socio-demographic characteristics of respondents and their opinions regarding brands or their behaviour respectively. The analysis and processing of primary data of the survey in this form provides new facts that have not been evaluated yet.

For the purpose of formulating of the conclusions and further recommendations the following statistical hypothesis have been put forward: 
H1: There is no statistically significant correlation between gender of consumers and their attitude that the branded product is of a higher quality than the non-branded product. H2: There is no statistically significant correlation between age of consumers and their attitude that the branded product is of a higher quality than the non-branded product. H3: There is no statistically significant correlation between education of consumers and their attitude that the branded product is of a higher quality than the non-branded product.

The verification of the hypothesis was carried out using the Chi-Square test (IBM SPSS Statistics, ver. 25). The Pearson's chi-squared test of independence is tested at the significance level of 0.05 . The question had to be answered on the rating scale1 to 5 (1 completely disagree, 3 - rather neutral, 5 - absolutely agree; where 1 to 2 imply rather negative attitude, and, otherwise, 4 to 5 imply rather positive attitude towards the branded product), which was to benchmark the statistical hypotheses, that were tested afterwards, using the independence test.

\section{Results and Discussion}

The first socio-demographic characteristics subject to analysis was gender, which were to determine the effect of the gender on consumer opinion: branded product is better quality than non-branded product. The hypothesis is as follows:

H0: There is no statistically significant correlation between gender of consumers and their attitude that the branded product is of a higher quality than the non-branded product.

H1: There is statistically significant correlation between gender of consumers and their attitude that the branded product is of a higher quality than the non-branded product.

Table 2. Gender vs quality of branded products.

\begin{tabular}{lllrrrrrr}
\hline & & & $\mathbf{1}$ & $\mathbf{2}$ & $\mathbf{3}$ & $\mathbf{4}$ & $\mathbf{5}$ & Total \\
\hline \multirow{3}{*}{ Sex } & Woman & Count & 96 & 207 & 345 & 265 & 90 & 1003 \\
& & Expected Count & 75,1 & 200,9 & 328,2 & 306,6 & 92,2 & 1003,0 \\
& Man & Count & 54 & 194 & 310 & 347 & 94 & 999 \\
& & Expected Count & 74,9 & 200,1 & 326,8 & 305,4 & 91,8 & 999,0 \\
\hline \multirow{2}{*}{ Total } & & Count & 150 & 401 & 655 & 612 & 184 & 2002 \\
& & Expected Count & 150,0 & 401,0 & 655,0 & 612,0 & 184,0 & 2002,0 \\
\hline
\end{tabular}

The survey sample is considered rather equally balanced when it comes to gender, thus making the sound basis for generalising of the findings and formulating of the further conclusions. The column Asymptotic Significance (2-sided) in the Table 3 includes the resulting $\mathrm{p}$-value of the independence test on correlation between gender of consumers and their preferences (opinions). Upon the p-value, which is lower than the present significance level standard value of 0.05 , the $\mathrm{H} 0$ null hypothesis regarding the independence of the variables is rejected and the alternate $\mathrm{H} 1$ hypothesis is accepted, i.e. the variables are dependent. Therefore, it is possible to consider the consumer's gender the sociodemographic characteristic determining the preferences and attitudes of consumers towards branded products in terms of their quality.

Table 3. Chi-Square Tests 1.

\begin{tabular}{lrrr}
\hline & Value & df & $\begin{array}{r}\text { Asymptotic Significance } \\
\text { (2-sided) }\end{array}$ \\
\hline Pearson Chi-Square & $25,118^{*}$ & 4 &, 000 \\
Likelihood Ratio & 25,310 & 4 &, 000 \\
N of Valid Cases & 2002 & & \\
\hline
\end{tabular}

* 0 cells $(0,0 \%)$ have expected count less than 5 . The minimum expected count is 74,85 . 
The Cramer's V coefficient and the contingency coefficient (Table 4), bringing more light on gender vs consumers opinion. Upon the quantified values of the coefficients involved, it proves weak dependence, which is the coefficient significance test of the variables is statistically significant, i.e. the dependence between the variables is weak, though statistically significant (systematic), and thus shall not be considered the random phenomenom (the approximate significance value is less than 0.05 ).

Table 4. Directional Measures 1.

\begin{tabular}{llrr}
\hline & & Value & $\begin{array}{r}\text { Approximate } \\
\text { Significance }\end{array}$ \\
\hline Nominal by Nominal & Cramer's V &, 112 &, 000 \\
& Contingency Coefficient &, 111 &, 000 \\
N of Valid Cases & & 2002 & \\
\hline
\end{tabular}

a. Not assuming the null hypothesis.

b. Using the asymptotic standard error assuming the null hypothesis.

c. Based on normal approximation.

The other socio-demographic characteristics subject to analysis was age; and the hypothesis is as follows:

H0: There is no statistically significant correlation between age of consumers and their attitude that the branded product is of a higher quality than the non-branded product.

H1: There is statistically significant correlation between age of consumers and their attitude that the branded product is of a higher quality than the non-branded product.

The contingency table (Table 5) provides respondent answers frequencies for individual age intervals.

Table 5. Age vs quality of brandet products.

\begin{tabular}{|c|c|c|c|c|c|c|c|c|}
\hline & & & 1 & 2 & 3 & 4 & 5 & Total \\
\hline \multirow[t]{12}{*}{ Age } & \multirow[t]{2}{*}{$16-25$} & Count & 36 & 98 & 126 & 137 & 41 & 438 \\
\hline & & Expected Count & 32,8 & 87,7 & 143,3 & 133,9 & 40,3 & 438,0 \\
\hline & \multirow[t]{2}{*}{ 26-35 } & Count & 37 & 88 & 121 & 133 & 44 & 423 \\
\hline & & Expected Count & 31,7 & 84,7 & 138,4 & 129,3 & 38,9 & 423,0 \\
\hline & \multirow[t]{2}{*}{$36-45$} & Count & 23 & 70 & 131 & 112 & 41 & 377 \\
\hline & & Expected Count & 28,2 & 75,5 & 123,3 & 115,2 & 34,6 & 377,0 \\
\hline & \multirow[t]{2}{*}{ 46-55 } & Count & 24 & 72 & 134 & 119 & 32 & 381 \\
\hline & & Expected Count & 28,5 & 76,3 & 124,7 & 116,5 & 35,0 & 381,0 \\
\hline & \multirow[t]{2}{*}{$56-65$} & Count & 26 & 59 & 107 & 80 & 21 & 293 \\
\hline & & Expected Count & 22,0 & 58,7 & 95,9 & 89,6 & 26,9 & 293,0 \\
\hline & \multirow[t]{2}{*}{ over 65} & Count & 4 & 14 & 36 & 31 & 5 & 90 \\
\hline & & Expected Count & 6,7 & 18,0 & 29,4 & 27,5 & 8,3 & 90,0 \\
\hline \multirow[t]{2}{*}{ Total } & & Count & 150 & 401 & 655 & 612 & 184 & 2002 \\
\hline & & Expected Count & 150,0 & 401,0 & 655,0 & 612,0 & 184,0 & 2002,0 \\
\hline
\end{tabular}

There were 6 age intervals set, each of them of the range of 10 years, and considered large enough to analyse for the effect of the age on consumers' preferences for branded products.

The resulting p-value of the independence test is higher than the significance level standard value (Table 6). The null hypothesis is acepted. Therefore, it is possible to consider the consumer's age the socio-demographic characteristic nondetermining the consumer attitude that the branded product is of a higher quality than the non-branded product. 
Table 6. Chi-Square Test 2.

\begin{tabular}{lccc}
\hline & Value & df & $\begin{array}{c}\text { Asymptotic Significance } \\
\text { (2-sided) }\end{array}$ \\
\hline Pearson Chi-Square & $22,339^{*}$ & 20 &, 322 \\
Likelihood Ratio & 22,861 & 20 &, 296 \\
Linear-by-Linear Association &, 008 & 1 &, 930 \\
N of Valid Cases & 2002 & & \\
\hline
\end{tabular}

* 0 cells $(0,0 \%)$ have expected count less than 5 . The minimum expected count is 6,74 .

The other socio-demographic characteristics subject to analysis was education, i.e. the effect of the level of education on consumers' attitude that the branded product is of a higher quality than the non-branded product. The hypothesis is as follows:

H0: There is no statistically significant correlation between education of consumers and their attitude that the branded product is of a higher quality than the non-branded product. H1: There is statistically significant correlation between education of consumers and their attitude that the branded product is of a higher quality than the non-branded product.

The contingency table (Table 7) provides respondent answers frequencies considering the highest level of education of the respondents.

Table 7. Education vs Branded Products Preferences.

\begin{tabular}{lllrrrrrr}
\hline & & $\mathbf{1}$ & $\mathbf{2}$ & $\mathbf{3}$ & $\mathbf{4}$ & $\mathbf{5}$ & Total \\
\hline \multirow{3}{*}{ Education } & basic/apprentice & Count & 96 & 215 & 347 & 297 & 116 & 1071 \\
& & Expected Count & 80,2 & 124,5 & 350,4 & 327,4 & 98,4 & 7071,0 \\
& \multirow{2}{*}{ secondary } & Count & 41 & 129 & 224 & 237 & 56 & 687 \\
& & Expected Count & 51,5 & 137,6 & 224,8 & 210,0 & 63,1 & 244 \\
& \multirow{2}{*}{ university } & Count & 13 & 57 & 84 & 78 & 12 & 244,0 \\
& & Expected Count & 18,3 & 48,9 & 79,8 & 74,6 & 22,4 & 244,0 \\
\hline \multirow{2}{*}{ Total } & & Count & 150 & 401 & 655 & 612 & 184 & 2002 \\
& & Expected Count & 150,0 & 401,0 & 655,0 & 612,0 & 184,0 & 2002,0 \\
\hline
\end{tabular}

From the point of view of education, there were 3 education intervals set, which are as follows: primary/vocational graduates, secondary graduates and university graduates respectively. The highest frequencies were identified with the primary/vocational graduates $(53.5 \%)$. The preferences within all the three intervals, however, are rather equally balanced.

The resulting $\mathrm{p}$-value of the independence test is lower than the significance level standard value (Table 8). The $\mathrm{H} 0$ null hypothesis regarding the independence of the variables is rejected and the alternate $\mathrm{H} 1$ hypothesis is accepted, i.e. the variables are dependent. Therefore, it is possible to consider the consumer's education the sociodemographic characteristic determining the preferences and attitudes of consumers towards branded products in terms of their quality.

Table 8. Chi-Square Test 3.

\begin{tabular}{lrcc}
\hline & \multicolumn{2}{c}{ Asymptotic Significance (2- } \\
& $24,130^{*}$ & df & sided) \\
\hline Pearson Chi-Square & 25,026 & 8 &, 002 \\
Likelihood Ratio &, 134 & 1 &, 002 \\
Linear-by-Linear Association & 2002 & &, 715 \\
N of Valid Cases & & \\
\hline
\end{tabular}

* 0 cells $(0,0 \%)$ have expected count less than 5 . The minimum expected count is 18,28 .

Table 9 provides the Cramer's V coefficient and the contingency coefficient values, proving weak dependency between the variables. 
Table 9. Directional Measures 3.

\begin{tabular}{llrr}
\hline & & Value & $\begin{array}{r}\text { Approximate } \\
\text { Significance }\end{array}$ \\
\hline Nominal by Nominal & Cramer's V &, 078 &, 002 \\
& Contingency Coefficient &, 109 &, 002 \\
N of Valid Cases & & 2002 & \\
\hline
\end{tabular}

a. Not assuming the null hypothesis.

b. Using the asymptotic standard error assuming the null hypothesis.

c. Based on normal approximation.

Upon the quantified values of the coefficients involved (Table 9), it proves weak dependence, which is the coefficient significance test of the variables is statistically significant, i.e. the dependence between the variables (education vs consumer opinion) is weak, though statistically significant (systematic), and thus shall not be considered the random phenomenom.

\section{Conclusion}

It is necessary to underline that preferences for branded products may differ significantly with individual consumers. Moreover, it is not possible to define the branded product explicitely, i.e. what some consumers would recognize the branded product, the others will not, and would rather find it just the reference product of no added value. However, almost each product on the market is associated with particular brand, and which are then distinguished by the level of personification of the brand, brand characteristics, market power and position of the brand in terms of competitiveness.

The findings of the survey proved that effective branding strategies shall, inter alia, pursue the socio-demographic trends. The socio-demographic characteristics of consumers (gender, age, education) we analysed, are considered the key determinants affecting the attitudes and preferences of consumers for branded products.

The socio-demographic characteristics, however, differentiate the markets, including the branded product markets; and thus the mono-brand market cannot satisfy all the consumer needs of all the market segments. Research results should be used when designing strategies for brands, focusing on the specific requirements and needs of individual consumer groups, accepting their demographic differences.

This paper is an outcome of project APVV-15-0505: Integrated model of management support for building and managing the brand value in the specific conditions of the Slovak Republic.

\section{References}

1. N. Wen, N. H. Lurie, The Case for Compatibility: Product Attitudes and Purchase Intentions for Upper versus Lowercase Brand Name. Journal of Retailing 94(4), 393407 (2018)

2. A. Krizanova, J. Majerova, T. Kliestik, P. Majercak, Theoretical Aspects of Brand Building in Seafood Industry. Nase More 60(5-6), 105-112 (2013)

3. J. Kliestikova, P. Durana, M. Kovacova, Naked Consumer's Mind Under Branded Dress: Case Study of Slovak Republic. Central European Business Review 8(1), 15-32 (2019)

4. C.O. Mirică (Dumitrescu), Judgments and Decision Making in Consumer Behavior: The Use of Psychophysiological Measures to Investigate Emotions and Cognitive Responses. Economics, Management, and Financial Markets 13(4), 39-44 (2018) 
5. L. Kanovska, Smart Services and Their Benefits for Manufacturers from a Global Perspective. Ekonomicko-manazerske spektrum 12(2), 46-56 (2018)

6. D. Mala, D. Bencikova, Innovations of a green product, Ekonomicko-manazerske spectrum 12(1), 64-74 (2018)

7. J. Vysekalova, J. Mikes, Image a firemná identita. Praha: Grada Publishing a.s. (2009)

8. D. A. Aaker, Measuring brand equity across products and markets. California Management Review 38 (3), 102-120 (1996)

9. M. Gogolova, J. Majerova, Analysis of the Communication Policy of Car Brand Skoda in the Slovak Market. Proceedings form the 2nd International Conference on Management Innovation and Business Innovation 44, (2014)

10. S. Moussa, M. Touzani, The perceived credibility of quality labels: A scale validation with refinement. International Journal of Consumer Studies 32(5), 526-533 (2008)

11. S. B. Yu, L. Hudders, V. Cauberghe, Seeling Luxury Products Online: The Effect of a Quality Label on Risk Percpetion, Purchase Intention and Attitude toward the Brand. Journal of Electronic Commerce Research 19, 16-35 (2018)

12. P. Suchanek, M. Kralov, The Influence of Customers' Personal Characteristics on their Satisfaction with the Food Industry. Journal of Competitiveness 10(4), 151-170 (2018)

13. J. L. H. Bowden, Engaging the student as a customer: A relationship marketing approach. Marketing Education Review 21(3), 211-228 (2011)

14. J. J. Singh, O. Iglesias, J. M. Batista-Foguet, Does having an ethical brand matter? The influence of consumer perceived ethicality on trust, affect and loyalty. Journal of Business Ethics 111(4), 541-549 (2012)

15. Y. C. Yang, High-involvement human resource practices, affective commitment, and organizational citizenship behaviors. The Service Industries Journal 32(8), 1209-1227 (2012)

16. V. Sierra, O. Iglesias, S. Markovic, J. J. Singh, Does ethical image build equity in corporate services brands? The influence of customer perceived ethicality on affect, perceived quality, and equity. Journal of Business Ethics 144(3), 661-676 (2015)

17. E. Nica, L. Taylor, New media technologies, digital sharing, and the neoliberal economy, Ekonomicko-manazerske spektrum 11(2), 103-110 (2017)

18. E.C.S. Santos, Brand portfolio strategy and brand architecture: A comparative study. Cogent business \& Management 5(1), 1-10 (2018)

19. N. A. Morgan, L. L. Rego, Brand portfolio strategy and firm performance. Journal of Marketing 73(1), 59-74 (2009) 